\title{
THE POSITIVE IMPACT OF COLLABORATIVE LEARNING FOR STUDENT WITH INTELLECTUAL DISABILITY IN INCLUSIVE SCHOOL
}

\author{
Nadya Muniroha, Mita Apriyanti ${ }^{\mathrm{b}}$, Siti Musayaroh ${ }^{\mathrm{c}}$, Syari Yuliana ${ }^{\mathrm{d}}$ \\ abcd Universitas Pendidikan Indonesia, Indonesia \\ e-mail: nadyamuniroh@gmail.com
}

\begin{abstract}
Collaborative learning in inclusive classroom is one of indicators to measure the succes of the implementation of inclusive education. The collaboration betwen regular student and student with intellectual disability (ID) in learning can contribute positive impact on the development of student with ID. The study aim to analyze the eminence of colaborative learning for student with ID in inclusive school. The method employed in this study is descriptive quantitative. The 30 regular students as the samples of this study were determined through simple random probability sampling. The primary data is collected via questionnaires and were accomplished with observation and unstructured interviews for secondary data. The data were analyzed by descriptive analitic. The result revealed that collaborative learning is enabled to build student characterics such as: caring, empathy, and social sensitivity. Collaborative learning can decrease in labbeling and bullying toward the existence of student with ID.
\end{abstract}

Keywords: collaborative learning, positive impact, student with intellectual disability

One of factors supporting the success of inclusive education is the positive attitude and confidence of all participants toward achieving the inclusive education golas.. Therefore, the positive attitude of regular students as the majority component of the interaction in the inclusive school becomes important things to note. A positive attitude is one of them can be seen from the collaboration of regular students along with students with special needs, especially on student with intellectual disability (Gonçalves \& Lemos, 2014).

In inclusive education, regular students learn alongside students with intelletual disability who have difficulties to build social interaction especially collaboration in the classroom (Ghergut, 2011; Mamas \& Avramidis, 2013; Agota, 2014). The acceptance of regular students toward student with intellectual disability and the appearence of new interaction patterns among them can be illustrated through how they collaborate in learning. One of the challenges in the implementation of inclusive education is how learning process in the classroom can accommodate the learning needs of each student and make every student feel a part of a learning community through participation (Kratochvílová, 2015).

Getting the opportunity to be received and cooperated in learning with regular students is an important part of the learning needs of students with intellectual disability (McLeskey \& Waldron, 2000). The diversity that can be accepted by the whole school community, especially by regular students, becomes one important measure of the success of inclusive education (Kasa \& Theoharis, n.d.). The dynamics of the relationship regular students with special needs students to be important to highlight (Gonçalves \& Lemos, 2014). How regular student attitudes toward students with disabilities in their schools? Is the existence of special needs students regularly disrupt student learning? Does the presence of students with special needs in the school environment which the majority are regular students even make them being bad labelling object when the process of interaction occurs? Or maybe, regular students really afford to be positive and accept the existence of special needs students in their schools, it is still a puzzle that needs to be pursued in fact (Booth\&Ainscow, 2002).

\section{METHOD}

This research uses descriptive quantitative method and analyzed using univariate analysis. The 30 regular students as the samples of this study were determined through simple random probability sampling. The primary data is collected via questionnaires and were accomplished with observation and unstructured interviews for secondary data. The research instrument in the study with a quantitative approach and descriptive methods are questionnaire using the Likert Scale. Data were analyzed descriptively by calculating the highest percentage in each of the indicators developed.

This research was conducted in SMP Negeri 10 Banjarmasin in 2014 that gave the opportunity to learn alongside regular students including students 
with special needs, including student with intellectual disability. :

\section{Figure 1. The Respon Of Regular Students to} Student with Intelletual Disability.

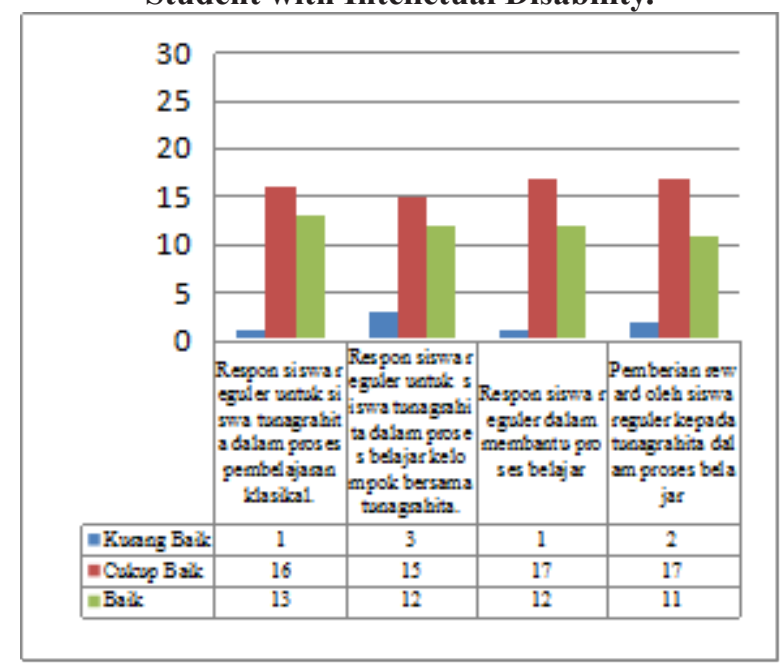

Figure 1. show about the quantitative data of positive impacts on students' collaborative learning in inclusive school betwen regular students and intellectual disability's students. It can be seen that the respon from regular student toward student with intellectual disability is good enough. The regular students can accept and collaborate with the special students.

\section{FINDINGS AND DISCUSSION}

\section{Findings}

Research data show that collaboration between the regular students with mental retardation as measured by student responses regular students to students with intellectual challenges in the learning process that the application is an attempt to establish communication in the learning process to student with intellectual disability in classical setting is already quite good, although not yet fully maximized. The response has been good enough this actually motivated by compassion that is too big to students with intellectual disability. They assume if in studying special students, they must always be helped, but if it continues to be difficult, they help special students to enhance its capabilities.

Generally, the response of regular students in assisting student with intellectual disability is quite good, which is consistent with the communication that was built by the regular students to assist in the classical learning of students with intellectual challenges, they generally have understood if the student with inellectual disability should not always be left to complete the task of the teacher, but it's better if students are given assistance appropriated with their needs.

The result of the study revealed that reward given by regular students is one of the indicators that collaboration in learning occured. Regular students happy to give praise and applause spontaneously if the student can complete the task from teachers, those reward aim to give support to students with intellectual disability in learning process.

Collaboration of regular students with students with intellectual disability during the learning process as a whole is dominated by the good results have implications on the other hand is that these relations could still be improved, see the willingness of regular students mingle in the study group with students with intellectual challenges that can stimulate such a positive impact social sensitivity and emphaty, then the program to improve the awareness of regular students to student with intellectual disability to continue its application through fun activities and teaching another .

\section{Discussion}

Regular students gathering together retarded students in one classroom had an impact on the formation of a new character in the study. The results support and elaborate previous studies by Hadwin, Jarvella, \& Miller (2016) who found that Socially shared regulation of learning (SSRL) occurs as a group-level phenomenon where students collectively negotiate and align common perceptions of the collaborative learning process and take control of the task through shared and negotiated, iterative finetuning of cognitive, behavioral, motivational and emotional conditions. How regular students willing to mingle with students with intellectual challenges and responded to their presence is regarded as one of the forms of collaboration in learning. Other studies have also highlighted the importance of collaborative learning example Isohatala, Jarvenoja, \&Jarvela (2017) found manifestations of SSRL involved more active participation than task focused interaction in general and that SSRL manifested most prevalently when all students in a group, rather than only some, contributed to the discussion and were attuned to each other's contributions.

The potential for increased optimization of learning by using a collaborative approach to regular students and student mental retardation seen in the results of this research into the assumption that learning in the classroom with students who have the characteristics of heterogeneous without separation both in terms of response to regular students against students with intellectual challenges when studying classical or in groups will still have a positive impact. These findings support Volet, Vauras, Salo, \&Khosa (2017) claim that 
study provided consolidated evidence of the importance of socially shared metacognitive regulation in student led productive collaborative learning, and novel evidence of the significance of individuals' flexible adoption of multiple roles, including content-focused roles in higher performing groups.

An atmosphere which seeks to combine learning between students with intellectual disability and regular students in one class, managed to stimulate a sense of empathy and grind labelling and bullying called frequently occur in inclusive school. Regular students working to provide a positive response to any attempt intellectual disability students to engage in the learning process, regular students did not refuse when combined with intellctual disability students in one group. (Frostad\&Pijl, 2007)

Those behaviour is a concrete manifestation of the positive side of collaborative learning. One of the goals of inclusive education for all citizens to learn to feel part of a community of learning in the classroom envisaged through this collaboration. (Kurth, Lyon, Shogren, 2015) Just behind the occurrence of this collaboration is not entirely due to the regular students have to understand that all children without exception are entitled to learn together with their collaboration demonstrated by a positive response from regular students to students with intellectual disability in the classroom is still influenced by pity. (Litvack, Ritchie, Shore, 2011) However this is not a big problem, because the willingness of regular students receive, respond positively and collaborate in learning with students with intellectual disability is a good start for the future needs to be improved, (Carter, et.al., 2007) for example through expanded opportunities for students with intellectual disability involved in school activities outside the classroom such as camping activities, youth red cross and other extracurricular possible. (Zaff, et.al, 2003; Pince \& Dymond, 2016; Kleinert, Miracle, Sheppard-Jones, 2007)

Schools in New York City is still relatively new in the application of inclusive education, including the school where he did research, the efforts of the school is good enough to make special needs students studying there. Schools do not do the separation of the place and time of learning between regular students and special needs students, but all students were blended in the same classrooms at the times to learn the same anyway. (Downing \& Peckham-Hardin, 2007)

The absence of a special modification of the curriculum also do not make regular students discriminates against students with intellectuaal disability. (Shogren, et.al, 2015) In contrast, peer tutorial is automatically created in heterogeneous learning environments like this. The positive impact of blending collaborative learning with regular students learn together in one classroom at a time and one teacher with students with intellectual disablity are more easily stimulated by conditions without distinction and separation like this. (Scruggs, et.al, 2006)

\section{CONCLUSION AND SUGGESTION}

The presence of students with special needs, including students who have intellectual disabilities and impress will always fall behind in learning was able to stimulate a sense of caring, empathy, and social sensitivity regular students. Through the research data can be seen in the fact that the regular student's response to the presence of special needs students in their learning environment is quite good and they can blend into the learning process. Social interaction skills of student with intellectual disability hampered by collaborative learning strategies have helped develop.

Schools organizing inclusive education is expected to increase the intensity of the implementation of the activities that involve students with special needs to build collaboration and social interaction actively with regular students should be more widely applied. For example by holding a camp devotion along the main purpose of the program is to stimulate awareness of regular students of the existence of special needs students in their schools as well as stimulate the regular students in order to address the presence of students with special needs with the right, do not pity the superfluous nor restrict association with them. These activities are designed attractive and should not be separated from the side of education as a foundation.

\section{REFERENCES}

Agota, Szekeres. 2014. Social Integration of Children with Mild Intellectual Disabilities in the Primary School. Procedia-Social and Behavioral Sciences, 116, 1855-1860. http://doi.org/10.1016/j. sbspro.2014.01.483

Booth, Tony and Ainscow, Mel. 2002. Index for Inclusion: developing learning and participation in schools. The Centre of Studies on Inclusive Education (CSIE). http://www.eenet.org.uk/ resources/docs/Index\%20English.pdf. Retrieved 24 January 2017. . 
Carter, Erik W. Et.al. 2007. Peer Supports as An Alternative to Individually Assignd Paraprofesionals in Inclusive High School Classrooms. Journal. Research and Practices for People with Severe Disabilities, Vol.32, No.4, pp.213-227.

Downing, June E., Peckham-Hardin, Kathryn D. 2007. Inclusive Education: What Makes It a Good Education for Students With Moderate to Severe Disabilities. Journal. Research and Practices for People with Severe Disabilities, Vol. 32, No. 1, pp. 16-30. rps.sagepub.com.

Frostad, P., \& Pijl, S. J. (2007). Does being friendly help in making friends? The relation between the social position and social skills of pupils with special needs in mainstream education. European Journal of Special Needs Education, 22(1), 15-30.

Ghergut, Alois. 2011. Education of children with special needs in Romania; Attitudes and experiences. Procedia -Social and Behavioral Sciences International Conference on Education \& Educational Psychology Procedia -Social and Behavioral Sciences, 112(112), 949-955. http:// doi.org/10.1016/j.sbspro.2014.01.1253

Gonçalves, Teresa \& Lemos, Marina. 2014. Personal And Social Factors Influencing Students' Attitudes Towards Peers With Special Needs. Procedia -Social and Behavioral Sciences International Conference on Education \& Educational Psychology Procedia -Social and Behavioral Sciences, 112(112), 949-955. http://doi. org/10.1016/j.sbspro.2014.01.125 $\underline{3}$

Hadwin, A.F., Järvelä, S., Miller, M. Self-regulation, coregulation and shared regulation in collaborative learning environments. In: D., Schunk, J., Greene, (Eds.). Handbook of Self-Regulation of Learning and Performance, 2016, Submitted.

Kasa, Christi \& Theoharis, Julie Causton. n.d. Strategies for Success: Creating Inclusive Classrooms that Work. www.pealcenter.org/images/PEALS4Success_20pg_web_version.pdf. Retrieved 24 January $20 \overline{17}$.

Kleinert, Harold L., Miracle, Sally A., Sheppard-Jones, Kathy. 2007. Including Students eith Moderate adn Severe Disabilitis in Extacurricular and Community Recreation Activities. Journal of Teaching Exceptional Children, Vol. 39, No. 36, pp. 33-38.

Kratochvílová, 2015. Learning Conditions - Part of the Support System for Pupils in an Inclusive Classroom. Procedia - Social and Behavioral Sciences, 186, 637-643. http://doi.org/10.1016/j. sbspro.2015.04.215
Kurth, Jennifer; Lyon, Krstin; Shrogen, Karrie. 2015. Supporting Students with Severe Disabilities in Inclusive Schools: A Descriptive Account From Schools Implementing Inclusive Practices. Journal. Research and Practices for People with Severe Disabilities, Vol. 40 (4) pg. 261-274. rps. sagepub.com

Litvack, Marla; Ritchie, Krista; Shore, Bruce. 2011. High and Average Achieving Students Perceptions of Disailities and of Students with Disabilities in Inclusive Clasrooms. Journal.Council for Exceptional Children. Vol 77 No. 4. Pp. 474-487. Journals.sagepub.com/doi/pdf/10.1

Mamas, Christoforos \& Avramidis, Alias. 2013. Promoting social interaction in the inclusive classroom: Lessons from inclusive schools in England and Cyprus. Learning, Culture and Social Interaction, 2(4), 217-226. http://doi. org/10.1016/j.lcsi.2013.07.001

McLeskey, James and Waldron, Nancy L.. 2000. Inclusive Schools in Action. The Association for Supervision and Curriculum Development (ASCD). http://www.ascd.org/publications/ books/100210.aspx, Retrieved 24 January 2017.

Pence, Alicia R., Dymond, Stacy K. 2016. Teachers' Beliefs About the Participation of Students with Severe Disabilities in School Clubs. Journal. Research and Practices for Persons with Severe Disabilites, Vol. 41 (I) pp. 52-68.

Scruggs, et.al. 2006. Differential Curriculum Enhancement in Inclusive Middle School Science: Effect on Classroom and High-Stakes Test. Journal. The Journal of Special Education Vol. 40/ No.3/2006/pp.130-137.

Shorgen, Karrie A., et.al. 2015. The Perspective of Students With and Without Disabilities on Inclusive Schools. Journal. Research and Practices for People with Severe Disabilities, Vol.40 (4) pp. 243-260. rps.sagepub.com.

Volet, S., Vauras, M., Salo, A.E., Kosa, D. 2017. Individual Contributions in student-led collaborative learning : insight form two analytical approaches to explain the quality of group out come. Learning and Individual Differences Journal. 53 (2017) 79-92. http:// dx.doi.org/10.1016/j.lindif.2016.11.006.

Zaff, Jonathan F., Moore, Kristian A., Papillo, Angela Romano., Williams, Stephanie. 2003. Implications of Extracurricular Activity Participation During Adolescence on Positive Outcomes. Journal of Adolescence Research, Vol. 18, No. 6, November 2003, pp. 599-630. 